\title{
3. GEOPHYSICAL SETTING OF DEEP SEA DRILLING PROJECT SITES 541, 542, AND 543, LEG 78A, BARBADOS ACCRETIONARY PRISM ${ }^{1}$
}

\author{
K. Ngokwey, A. Mascle, and B. Biju-Duval, Institut Français du Pétrole ${ }^{2}$
}

\section{INTRODUCTION}

To investigate the deformation front of an accretionary wedge along an active margin, the IPOD Mediterranean-Caribbean Subpanel selected an area located in front of the Barbados accretionary prism where the Atlantic ocean crust and the lower part of its sedimentary cover are underthrust underneath the Barbados Ridge complex, east of the Lesser Antilles arc. This site was surveyed in March 1976 by IFP-CNEXO, and the preliminary results were presented at the Eighth Caribbean Conference, Curaçao, 1977 (Biju-Duval et al., 1978). The location of the site, approximately $200 \mathrm{~km}$ east of Marie Galante and Dominica islands, is between $15^{\circ} 30$ to $16^{\circ} 00 \mathrm{~N}$ and $58^{\circ} 20$ to $59^{\circ} 00 \mathrm{~W}$ (Fig. 1).

In this area the Atlantic abyssal plain lies at about 5600 to $5800 \mathrm{~m}$ below sea level, between the Tiburon and Baracuda rises, which represent elongate ESE-WNW elevations of the Atlantic ocean crust (fracture zones). The site area at the northwest end of Tiburon Rise is marked by a general northeastward deepening of the seafloor, at the lower slope of the Barbados Ridge complex. On the bathymetric map one can observe a bending of the Barbados Ridge wedge along the Tiburon Rise (see Fontas et al. and Belderson et al., this volume, for detailed morphology).

As shown by previous multichannel seismic lines (Shell Line C 2714, CEPM Line A3; see back pocket Plate 1D), north of Tiburon Rise the ocean crust is covered by a thin sedimentary sequence (between 0.3 and $0.6 \mathrm{~s}$ two-way traveltime) probably composed of pelagic and hemipelagic sediments. The narrow and thin aspect of the northern part of the Barbados Ridge complex enables us to follow seismic tracing of the ocean crust and a part of its thin cover beneath the apparently tectonized sediments constituting the Ridge (see discussion in Westbrook et al., this volume, and Figs. 2 and 3).

The objectives of the IFP-CNEXO site survey were to investigate this area to define the best location for drilling at the toe of the presumed allochthonous sequence. Our critical goal was to minimize penetration to the undisturbed sediments and the ocean crust. The main objectives were to document the tectonic character of the deformation front of the accretionary wedge (set of overthrusts?, offscraped sediments?, slide accumulations?)

\footnotetext{
${ }^{1}$ Biju-Duval, B., Moore, J. C., et al., Init. Repts. DSDP, 78A: Washington (U.S. Govt. Printing Office).

Onges: (Ngokwey and Mascle) Institut Français du Pétrole, B. P. 311, 92506 Rueil. Malmaison, France; (Biju-Duval, present address) Centre National pour l'Exploitation des Océans, 66 Avenue d'léna, 75116 Paris, France.
}

and define lithology and age of layered sediments and ocean crust. The IFP-CNEXO survey (carried out with the Florence of IFP) obtained about $260 \mathrm{~km}$ of multichannel seismic lines (Lines A1A to A1F, Fig. 4). In addition, another line (CRV 001) had been obtained later by CEPM (CARVEN project, see Fontas et al., this volume).

\section{CHARACTERISTICS OF THE SEISMIC EQUIPMENT AND DATA}

Lines A1A to A1F were obtained with the IFP Flexichoc source. This is a purely implosive system; the implosion is created by the spreading apart and sudden release of two circular metal plates held together by an elastic joint (pneumatic gun of 123-20 type). The source is placed at about a $13-\mathrm{m}$ depth, and the signal is generated by transformation of the kinetic energy of the water above and below the plates into an acoustic pulse. Advantages are the quality of the signal (only one positive peak signature, no bubble effect) and the frequency of shooting.

Our normal streamer has 48 tracks; but it was damaged early in the survey, we therefore used a shorter streamer of only nine tracks $(50 \mathrm{~m}$ between each track, submerged at 15-25 m). Recording was coupled with real-time processing (giving dynamic corrections), which produces good results in deep water. A fully integrated satellite navigation system was used.

Reprocessing of the lines has been done, but because of the short streamer used for the survey, the imagery was poorly enhanced. Velocity information is also very poor, and so good migrations were difficult to get (Fig. 5). In fact, the velocity data used come from a twentyfold A3 CEPM profile. The accuracy of the interval velocities is still reduced because of the great water depth and the velocity analyses.

The CRV 001 line is also a multichannel seismic (MCS) line but uses the high resolution system of several small Flexichoc guns (FHC 50) operating simultaneously and giving a 10 -m vertical resolution (Fig. 6).

\section{SEISMIC STRATIGRAPHY}

In this study area we distinguished a westward upper sequence in which the top is seafloor and the bottom is the top contact of Reflector 1 (Fig. 7); this sequence has an acoustically "discontinuously reflective" character, without a coherent continuous reflector. This seismic unit rapidly diminishes in thickness to the east toward the Atlantic abyssal plain. At the base of the slope it loses its chaotic internal configuration and laterally 


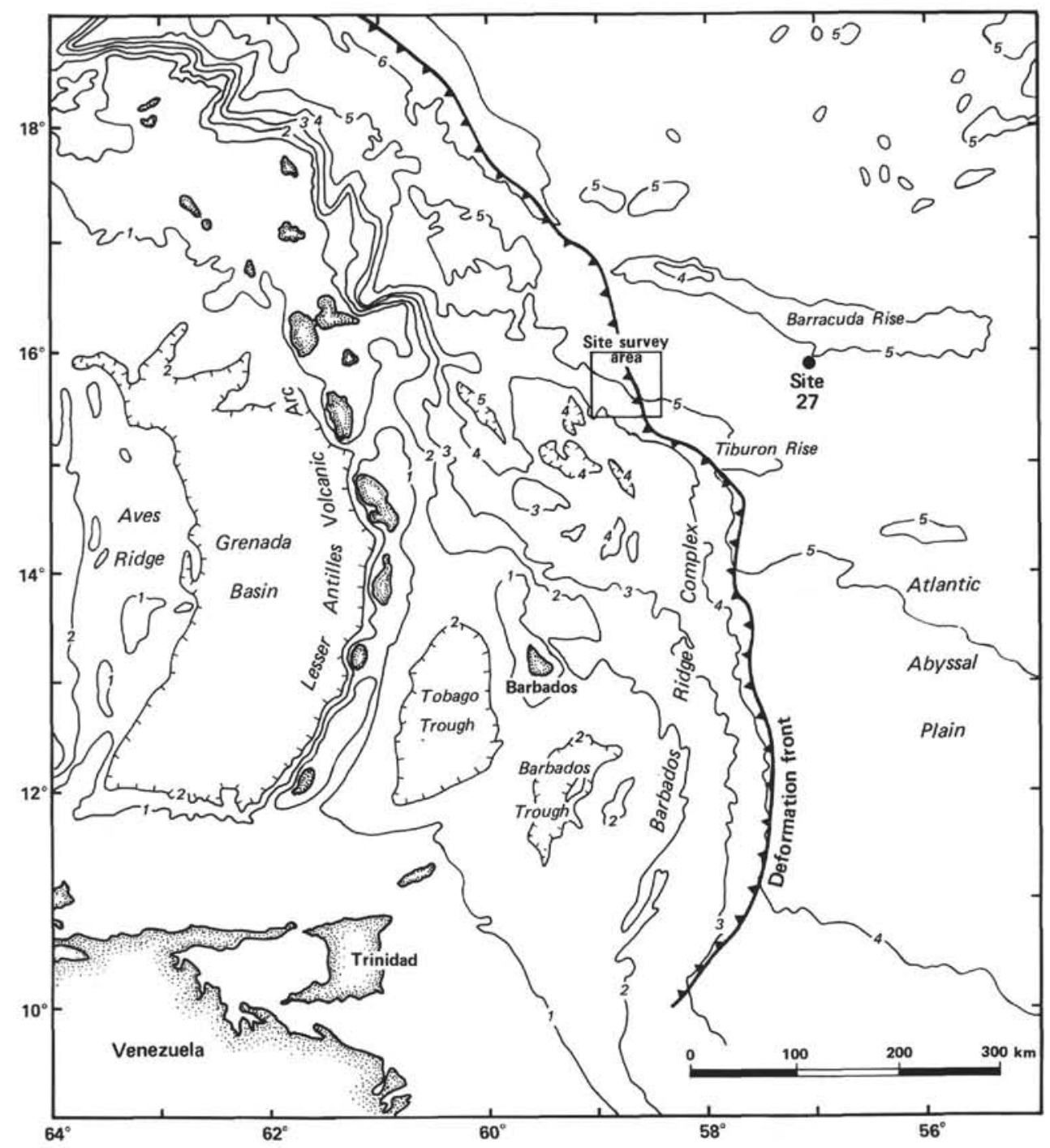

Figure 1. Location map of the site survey area at the deformation front of the Barbados Ridge complex.

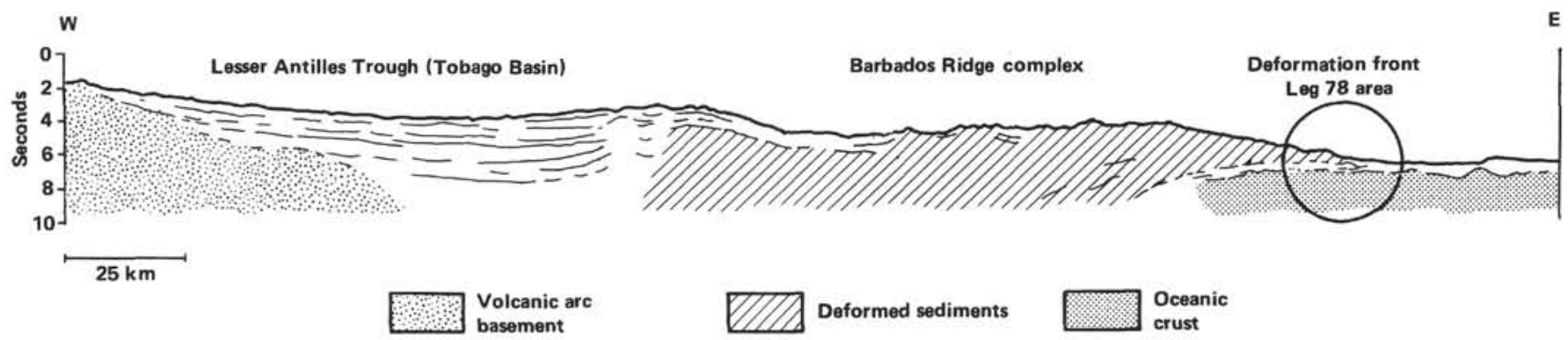

Figure 2. Line drawing of CEPM Line A3. This section gives the general characteristics of the Lesser Antilles active margin east of Guadeloupe Island, from the volcanic arc to the Atlantic abyssal plain.

passes to the slightly reflecting upper subunit of the layered sequence (Subunit 1). This boundary is interpreted as the deformation front of the Barbados Ridge complex and trends north-south in the whole area (Fig. 8). Because of poor resolution within this seismic unit, the internal structure of possible frontal deformation is difficult to determine.
We distinguished also a lower sequence of flat-lying, layered reflectors above the acoustic basement. The westward top of this sequence is the top of prominent Reflector 1 , underneath the upper sequence; its eastward top is seafloor. The bottom of this sequence is the hyperbolic acoustic basement presumed to be the ocean crust (Layer 2). Reflectors in this sequence are charac- 


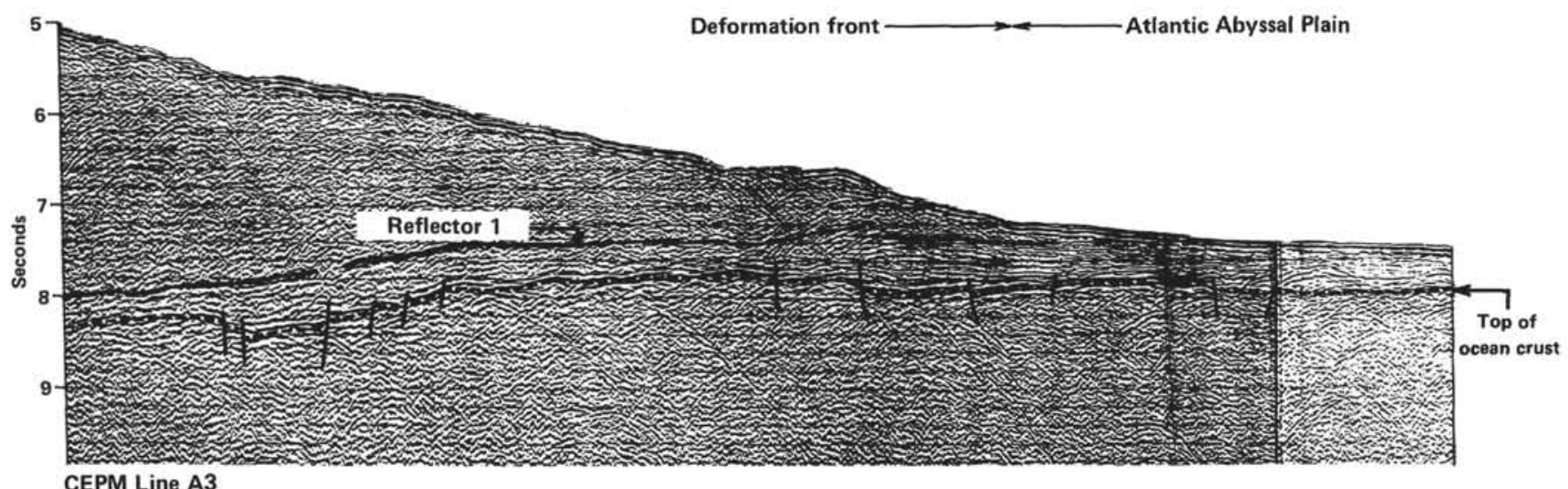

Figure 3. Main structural sequences at the deformation front. Below the lower slope between the seafloor and Reflector 1, there is an acoustically discontinuously reflective subunit interpreted as a pile of deformed sediments. Between Reflector 1 and the top of the ocean crust there is a well-layered sequence of reflectors interpreted as an autochthonous tegument above the ocean crust. A very diffracting acoustic basement is interpreted as the ocean crust.

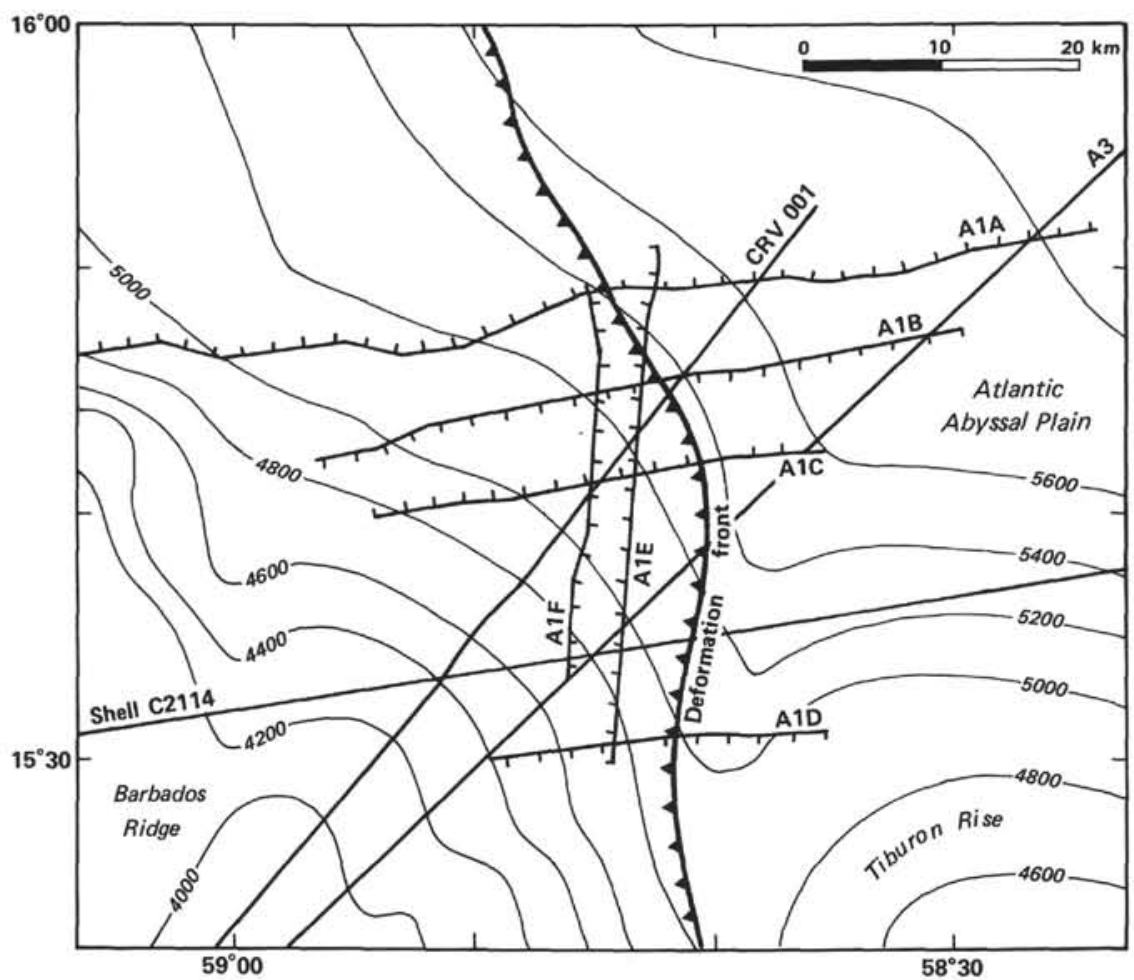

Figure 4. Location map of the site survey; water depths in meters.

terized by variable amplitude and continuity. Nevertheless, below Reflector 1, another quite continuous reflector, Reflector 2, is observed, which allows definition of two subunits underneath the discontinuously reflective sequence: An upper subunit (Subunit 2), generally uniform in thickness (about $0.3 \mathrm{~s}$ two-way traveltime), extends from beneath the abyssal plain to within at least $20 \mathrm{~km}$ west of the deformation front. A lower subunit (Subunit 3), about $0.2 \mathrm{~s}$ two-way traveltime at Site 541, shows rapid lateral variations in thickness and pinches out against bedrock high to the west (A1D profile) and northward (A1E and A1B profiles). We interpret these two subunits as the sedimentary column resting on the downgoing Atlantic ocean crust; this sedimentary section is presumably being subducted beneath the tectonized (offscraped?) upper sedimentary pile underlying the Barbados Ridge.

\section{LATERAL VARIATIONS}

By using all the seismic lines, we can broadly define the characteristics and variations of these sequences in the site area. 


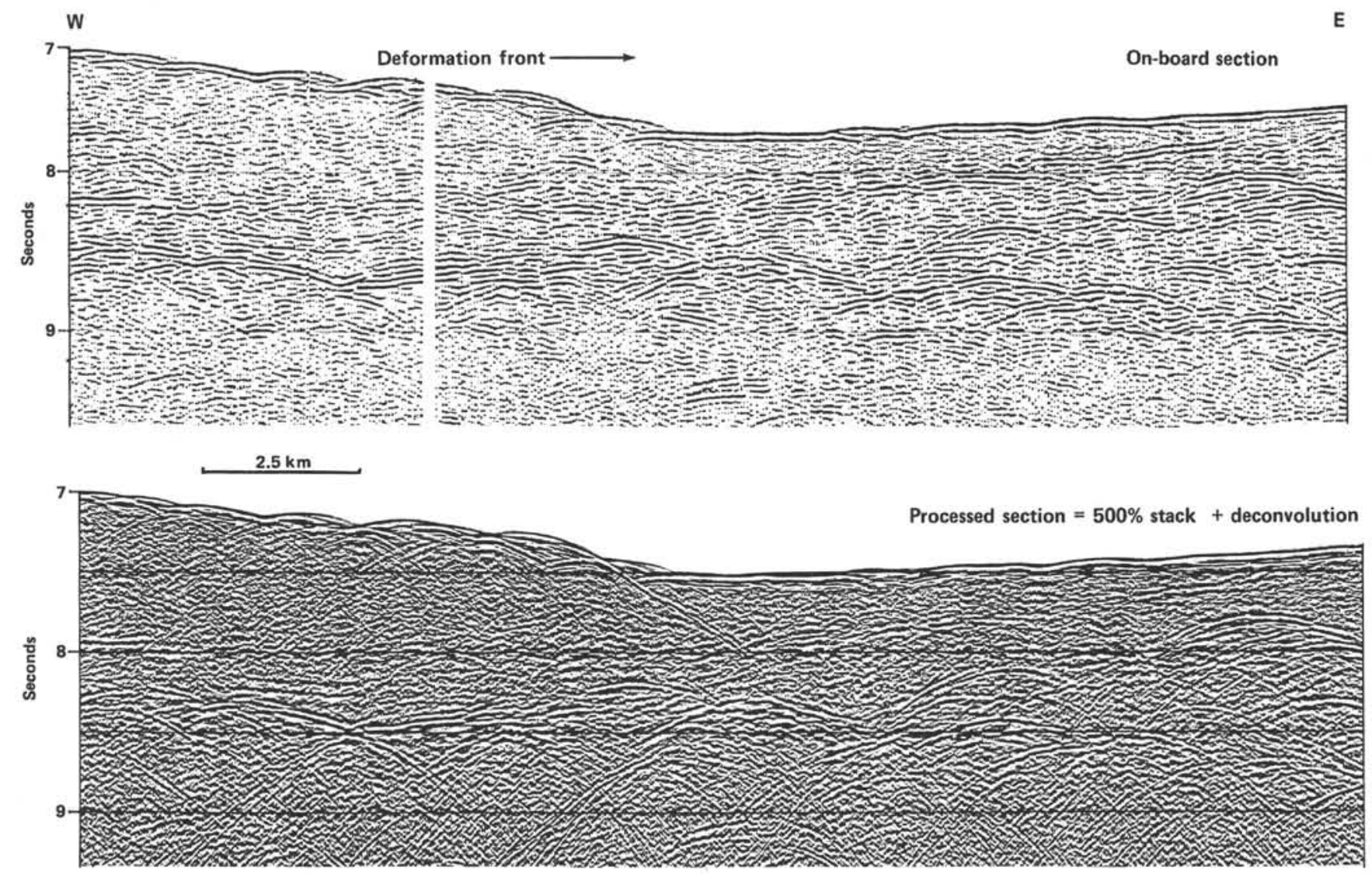

IFP - CNEXO Line AIA

Figure 5. Comparison between on-board and processed sections.

Total sediment thickness. Figure 9A shows that total thickness of sediments is very reduced in the abyssal plain (less than $0.6 \mathrm{~s}$ two-way traveltime). The deformation front is well marked with a rapid thickening landward; on the upper slope the thickness is up to $4 \mathrm{~s}$ two-way traveltime. We also note that a thickening on the Tiburon Rise and a more accentuated one northward (Fig. 10) may be due to the result of a transverse fracture zone. Figure 9B, using interval velocities, is a map of converted isopachs in meters. Because we used intervalvelocity values higher than velocities measured on the core samples (see Marlow et al., this volume), the thicknessess shown on this map are certainly too great.

Depth of the basement. The isotime map of the acoustic basement depth shows that Atlantic ocean crust deepens from $7.4 \mathrm{~s}$ two-way traveltime in the southeast to more than $9.0 \mathrm{~s}$ two-way traveltime in the northwest (Fig. 11A). This phenomenon is partly the result of the northward deepening of the seafloor (Fig. 1) but also the result of thickness variations of the sedimentary sequences and tectonic thickening of the prism. Figure 11B shows such a northwestward deepening of the top of an undisturbed flat-lying sequence from 6.8 to $8.2 \mathrm{~s}$ two-way traveltime. For instance, on profile A1E this general deepening is well observed (Fig. 12). In some places local elevations of the basement were observed (unmapped). Some of them can be interpreted as initial faulted highs, as demonstrated by progressive sediment onlapping (Fig. 13). This interpretation suggests a possible buried fracture zone with probable recent displacement, as indicated by present topography (around $250 \mathrm{~m}$ of elevation) and the chaotic aspect of the reflectors in the sediments above the faulted zone.

Thinning of the lowermost Subunit 3 (below Reflector 2). Because of the irregularities of the basement topography one can observe local thinning of the lowermost subunit, illustrated on Profile A1C (Fig. 13).

Thickness variations of Subunit 2 (between Reflectors 1 and 2). Thickening is observed on the northern part of the survey. This variation explains a large part of the total sediment thickness of Figure 9. The influence of tectonic processes and currents acting along possible fracture zones cannot be ruled out.

Structure of the discontinuously reflective unit. Reflector 1, the first prominent reflector that defines the bottom of the discontinuously reflective unit, is generally very continuous. But it can be affected by disruptions, as indicated on Profile A1D (Fig. 7). Locally, for instance, on Profile A1F the bottom of this unit is not parallel to the layered sequence: we observe here the disappearance of Subunit 2, which seems truncated by the tectonized unit (Fig. 14). The internal structure of the 


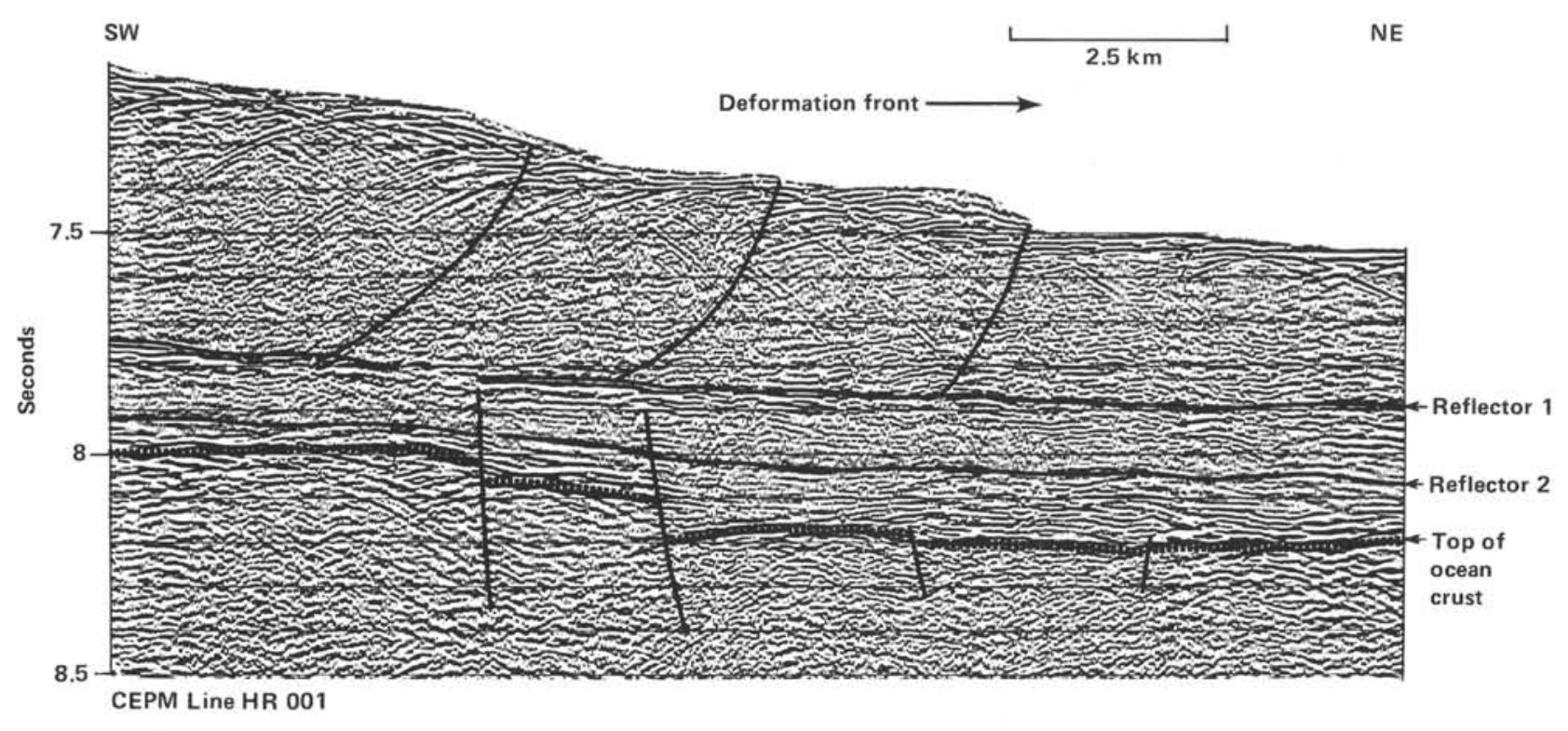

Figure 6. High resolution CEPM multichannel seismic line HR 001. Better resolution is achieved than in Figure 5. Nevertheless the internal structure of the upper unit (above Reflector 1) is badly understood. Drawing of the reverse fault is highly speculative before drilling information is obtained. This profile allows the definition of Reflector 2 into the layered sequence.

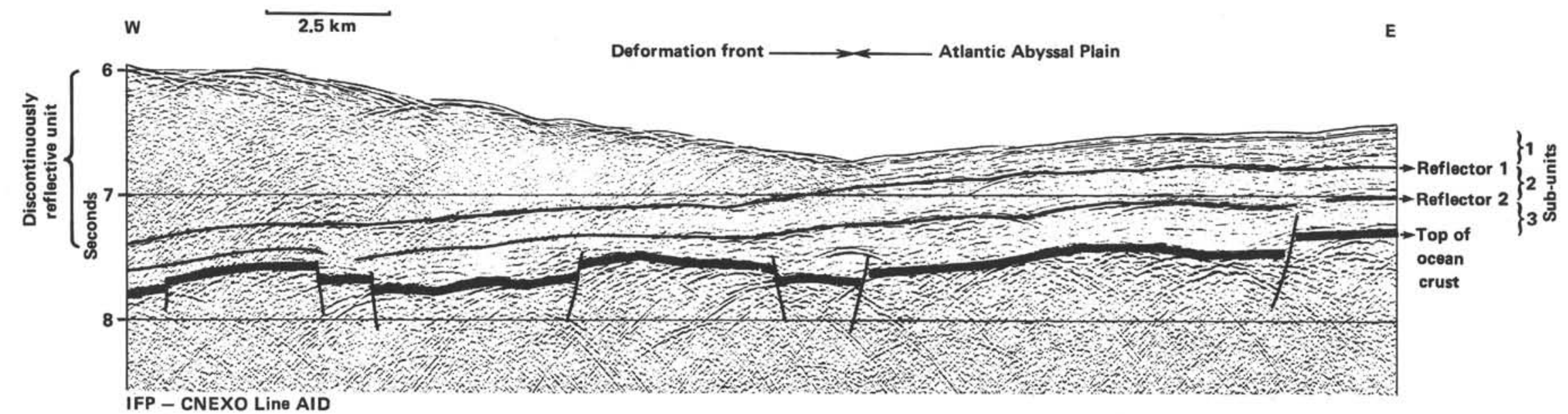

Figure 7. Line A1D, a typical section through the deformation front, shows the acoustically discontinuously reflective subunit on top of the layered sequence close to Sites 541 and 542. 


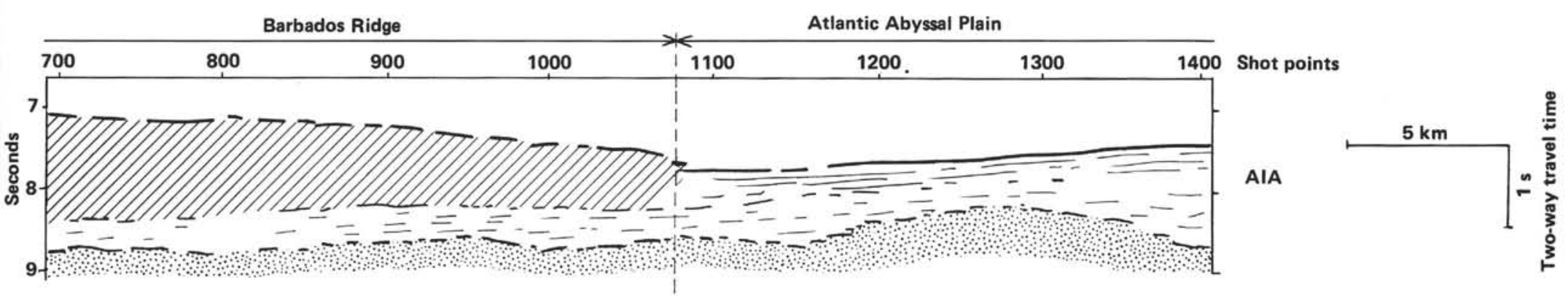

Barbados Ridge

Shot points

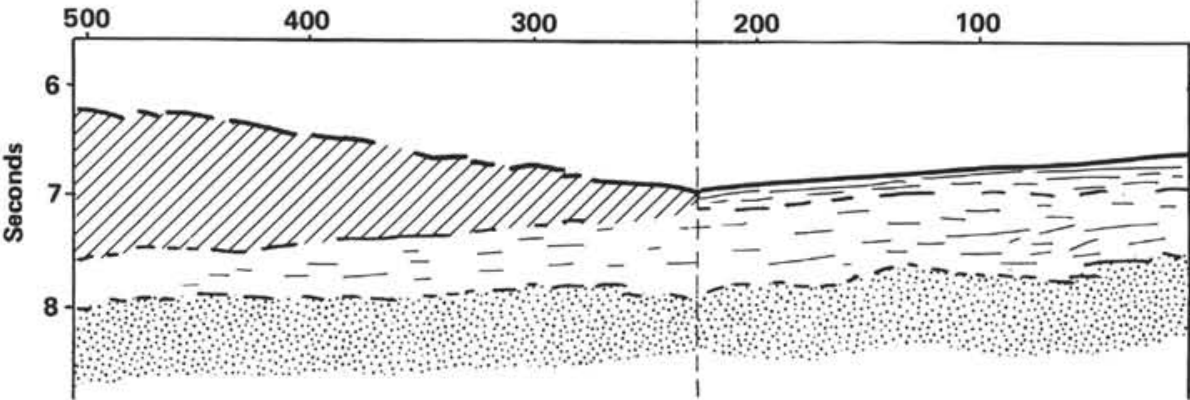

AID

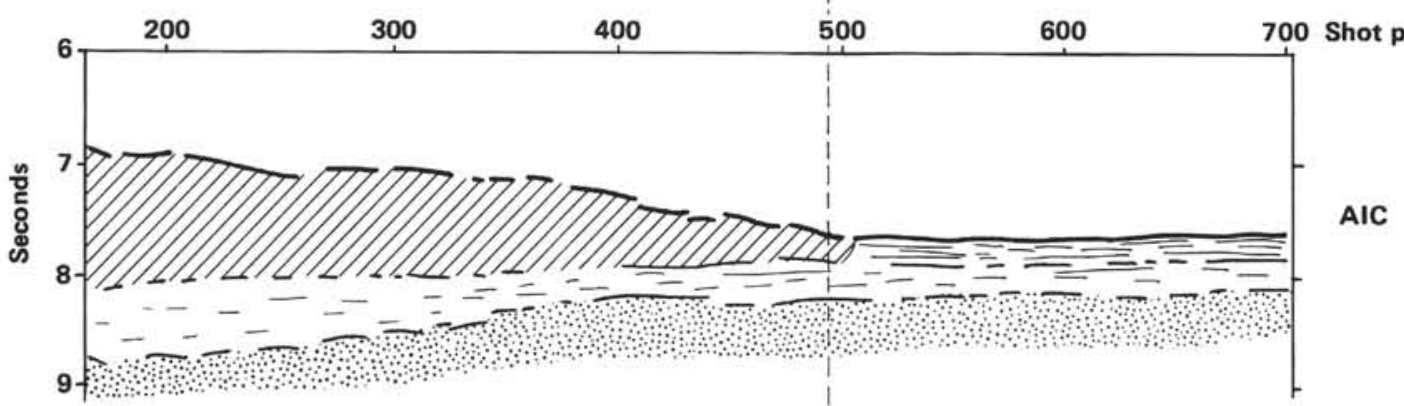

AD

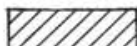

Tectonized unit

$\overline{\bar{I}} \overline{-}$ Undisturbed unit

Acoustic basement

Figure 8. Interpreted sections of Lines A1A, A1C, and A1D through the deformation front showing the continuity of the seismic units from north to south of the survey and local thickness variations. 


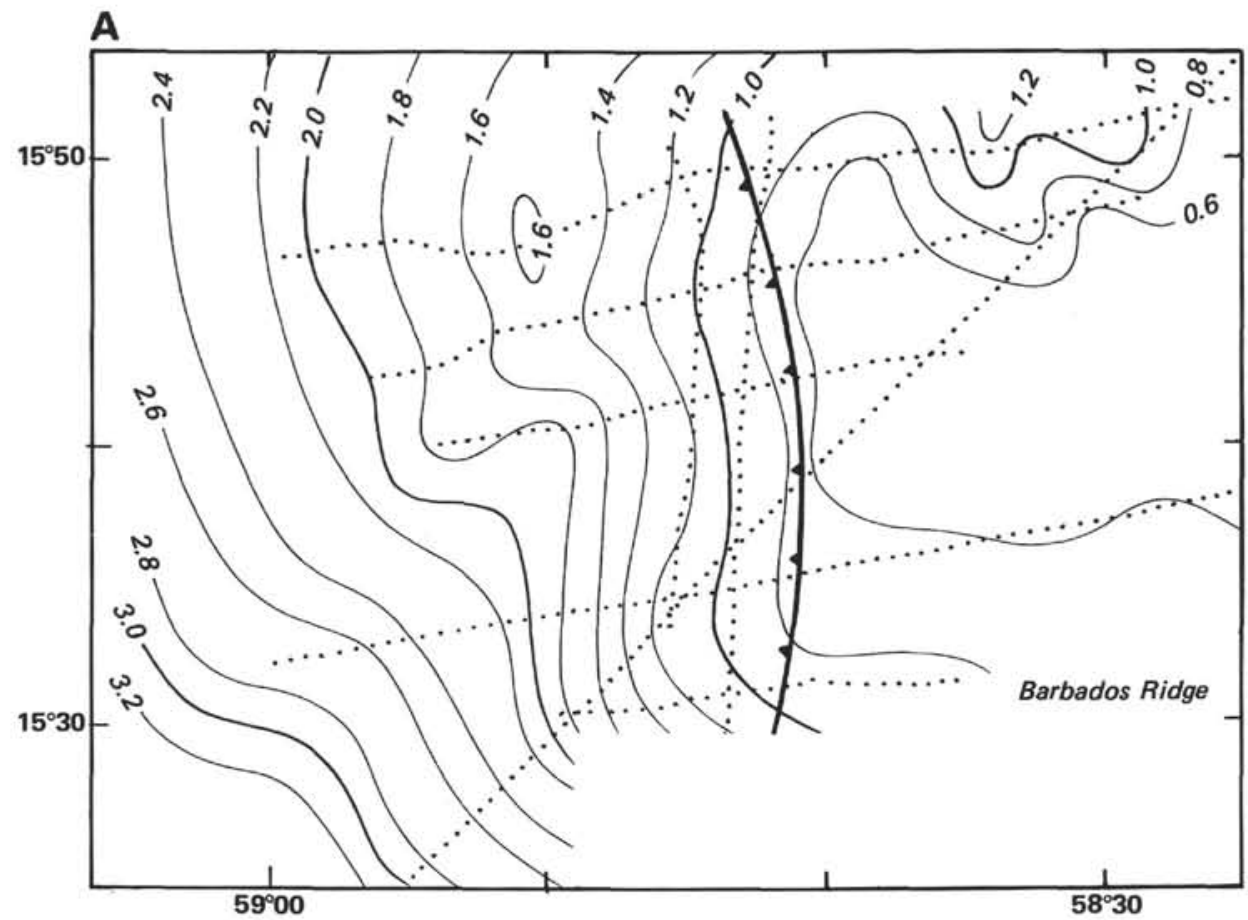

B

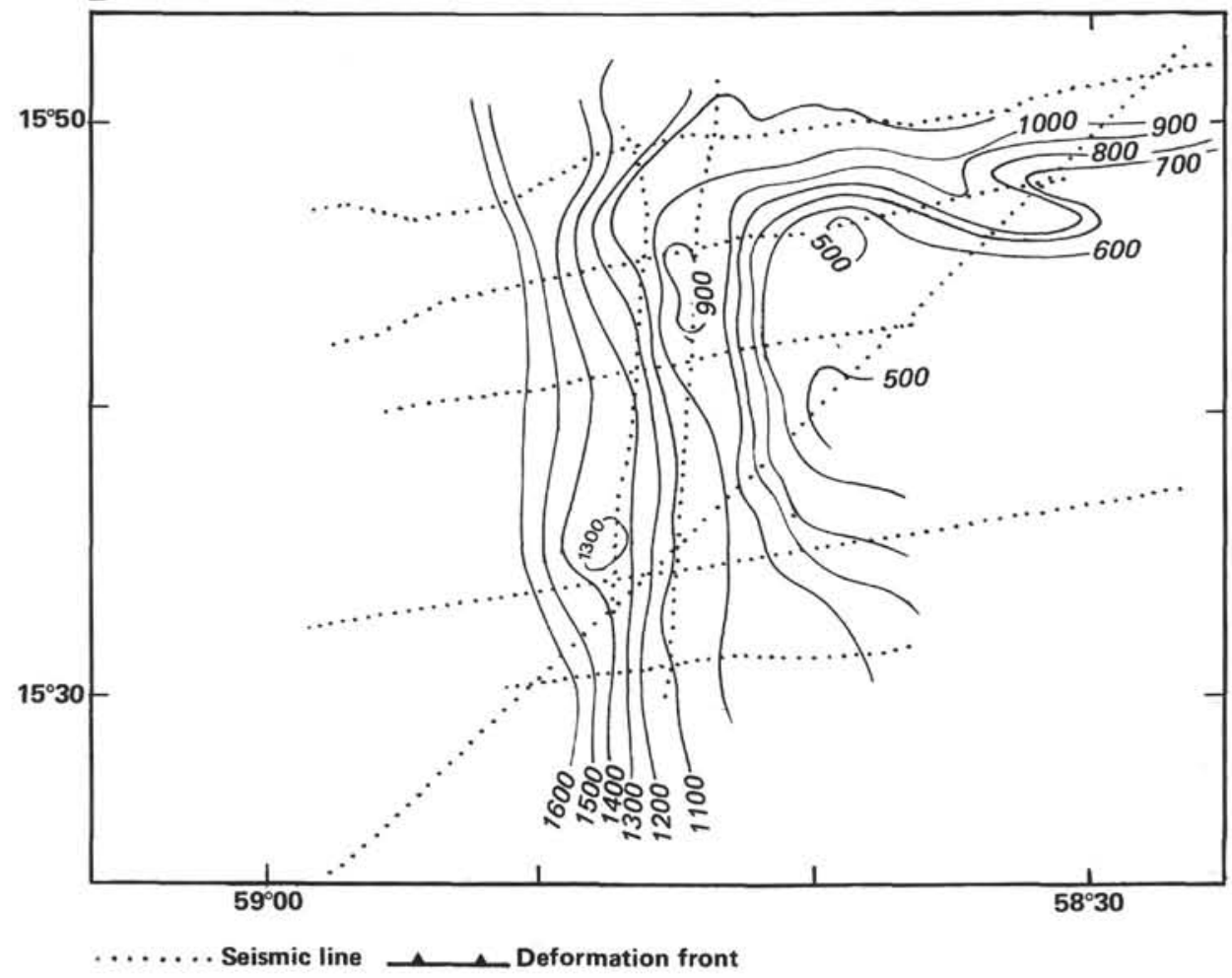

Figure 9. Total sediment thickness A. in time(s) and B. converted in meters. 


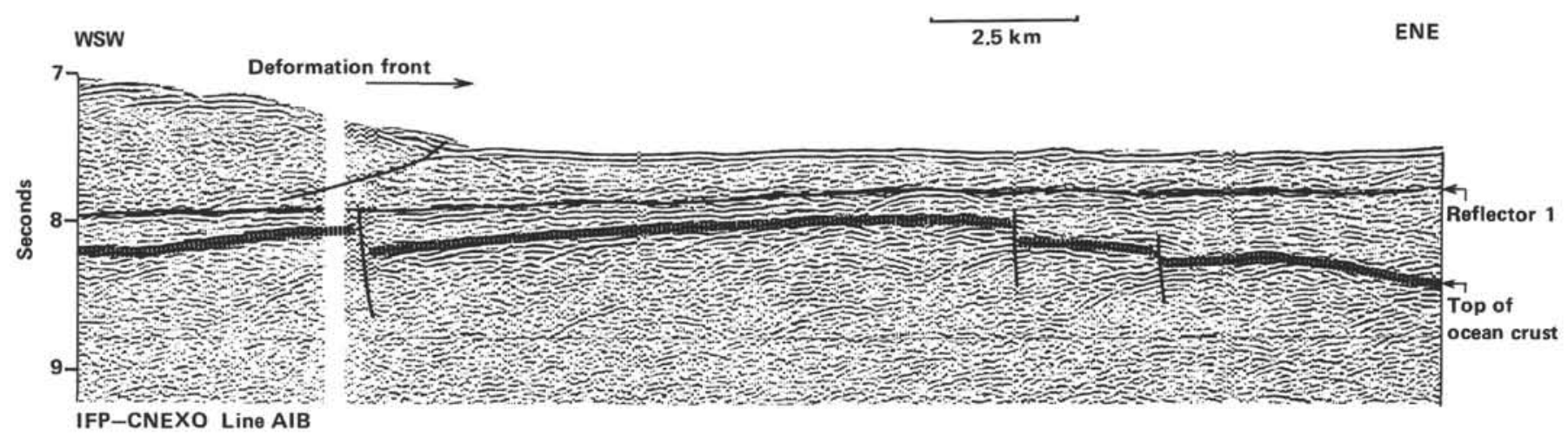

Figure 10. Example of the faulted ocean basement and correlative thickening of the infra-Reflector 1 sequence.

discontinuously reflective unit is not obvious. Sometimes landward dipping discontinuous reflectors are observed, for example, on the monitors of CEPM Line A3 or Line A1D (they disappear on the processed sections possibly because of inappropriate velocity functions used in the reprocessing). Such dipping reflectors are visible on Figure 8 . Use of the high resolution system allows better resolution of these internal features (Fig. 6). Our initial interpretation was that an apparent polarity inversion of Reflector 1 suggested that the interval velocity of the discontinuously reflective unit was greater than that of the deeper, flat-layered sequence. However, velocity measurements on board do not support such a contrast (see Marlow et al., this volume).

\section{CONCLUSIONS}

This site survey provided useful information on the structure of the region, before drilling was begun. The basement morphology is irregular on a great scale because of the presence of the Tiburon Rise as well as a possible transverse fault zone to the north. Basement relief is also irregular on a small scale, with considerable relief and buried fault scarps evident even well away from the Tiburon Rise. Thus hiatuses, condensed sections, and thickened sections are probable in the oldest sediment, and facies may vary greatly over short distances.

The sedimentary column deposited on the Atlantic abyssal plain is made up of a lower sequence (Subunits 2 and 3) deposited on the ocean crust, without apparent deformation below the deformation front, and a superficial series (Subunit 1) that is being incorporated in a tectonized wedge (discontinuously reflective unit). The contact between the two is relatively flat, as a décollement.

The loss of acoustic energy to the west where the prism thickens does not permit us to know how far to the west the undisturbed series are carried with the crust.

We note a certain independence between the basement structure (dipping to the northwest, plus thickening of the lower sequence) and the north-south trend of the deformation (plus westward thickening), which is linked with the east-west shortening (motion of plates). Seismic profiling is unable to resolve the internal structure in the tectonized wedge. But this submeridianal front of deformation together with westward thickening suggest that there must be several superimposed tectonic units (sets of offscraped sediments?). These formed at the same time as large gravity slides, at least on the lower part of the slope.

\section{REFERENCES}

Biju-Duval, B., Mascle, A., Montadert, L., and Wannesson, J., 1978. Seismic investigations in the Columbia, Venezuela and Grenada Basins and on the Barbados Ridge for the future IPOD Drilling. Geol. Minj., 57:105-116.

Date of Initial Receipt: August 11, 1982

Date of Acceptance: September 20, 1983 


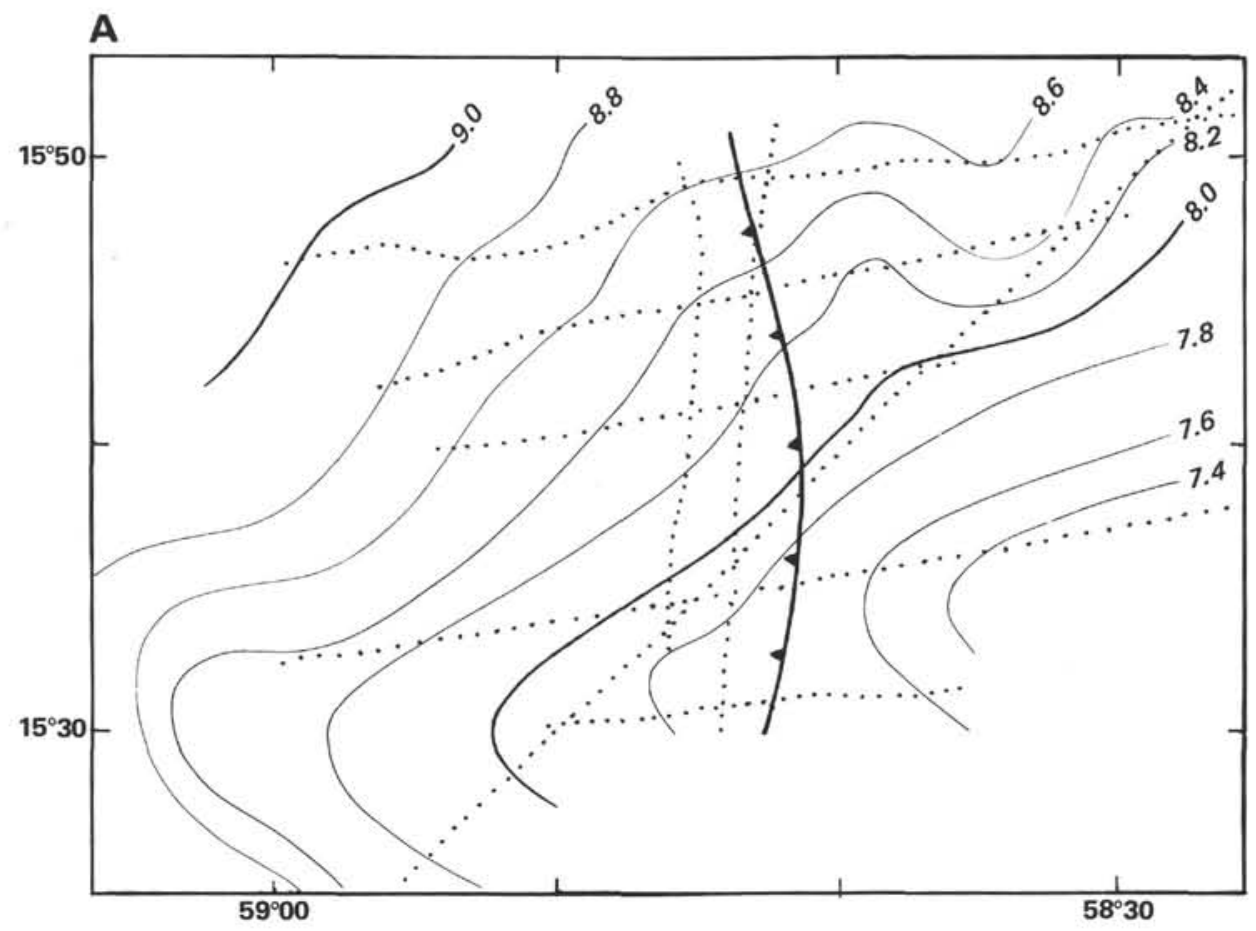

B

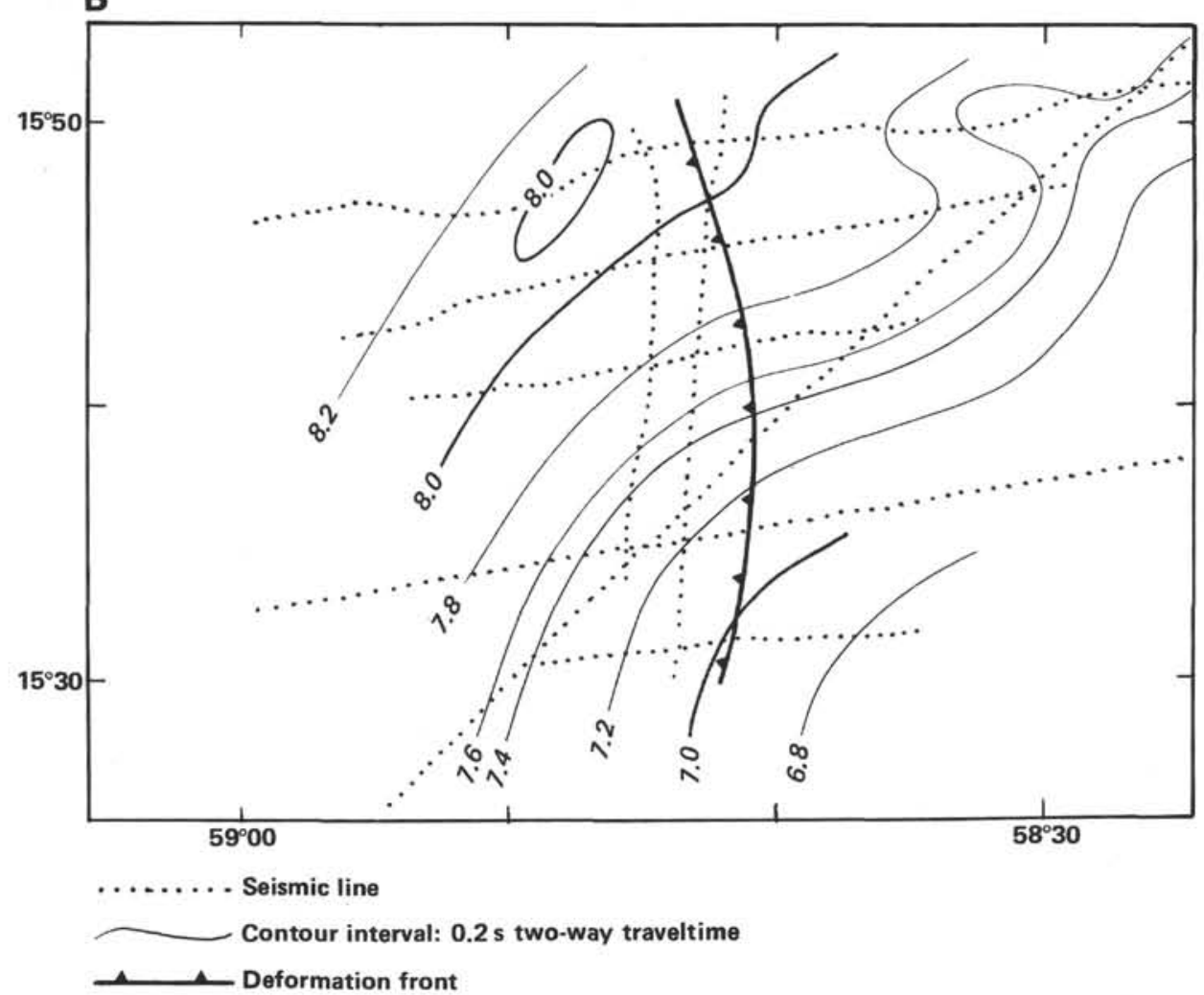

Figure 11. A. Isotime map of the basement showing the northwest deepening of the basement oblique to the deformation front and the seafloor topography. B. Isotime map of Reflector 1; note the northwest deepening of Reflector 1 oblique to the deformation front. Contours are given in seconds of two-way traveltime. 
N

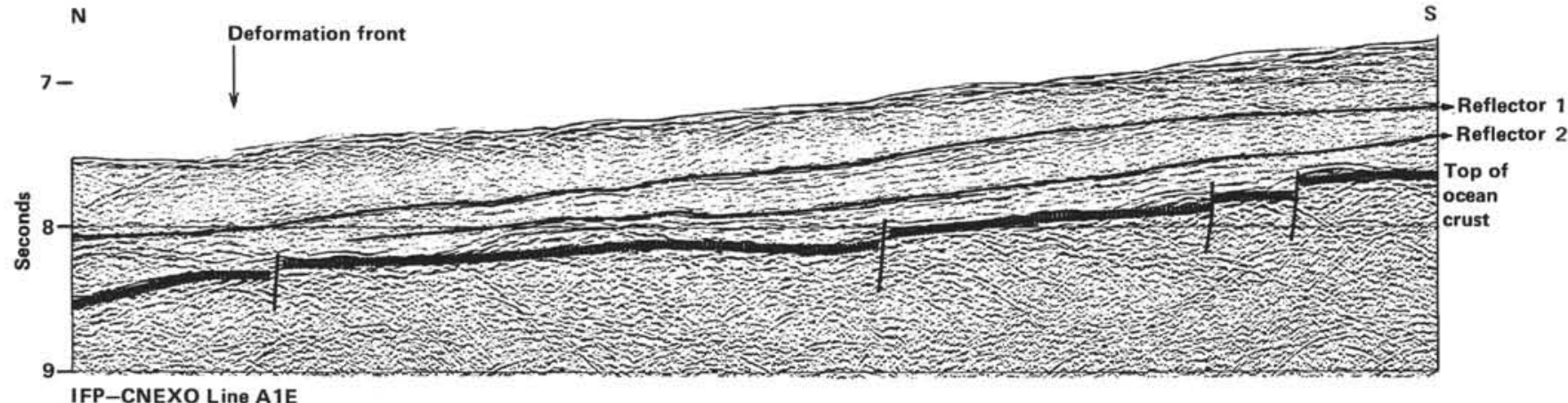

Figure 12. Northward deepening of the basement on Profile AlE. Over $50 \mathrm{~km}$ from south to north, the top of ocean crust deepens about $1 \mathrm{~s}$ (1000 m).

\section{$2.5 \mathrm{~km}$}

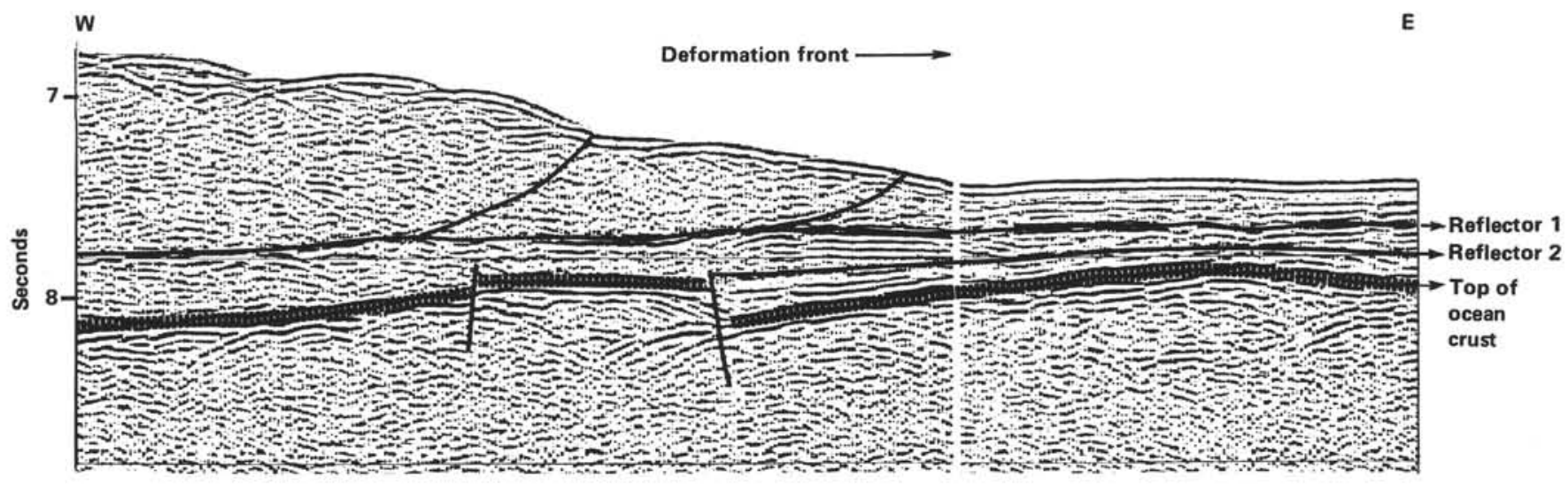

IFP-CNEXO Line A1C

Figure 13. Faulted basement highs on Line A1C below the toe of Barbados Ridge. Note the thickness variation of Subunit 3 below Reflector 2.

\section{$2.5 \mathrm{~km}$}

\section{s}

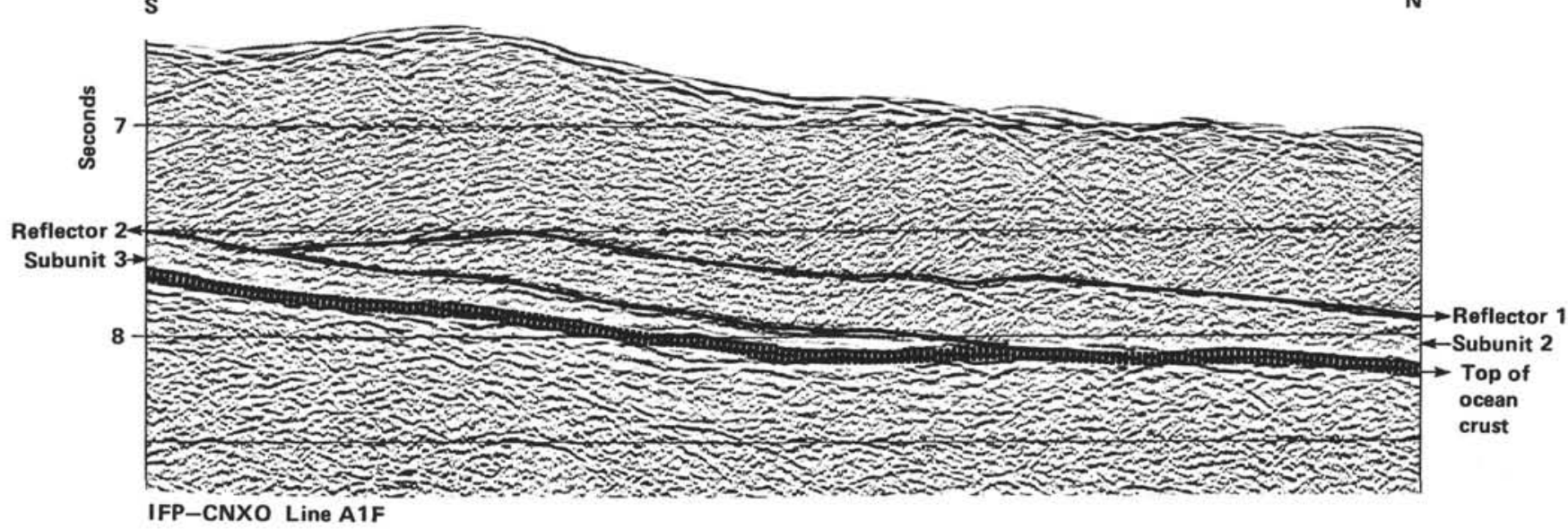

Figure 14. Example of thickness variation of Subunits 2 and 3 on Line AlF. Subunit 3 thins northward due to the basement topography (it may be very thin on the high but is not resolved by conventional seismic means). Subunit 2 thins to the south along a surface interpreted as a tectonic truncation. If true, this interpretation would mean that at least locally the décollement is not along a stratigraphic level and that Subunit 2 is scraped off too. 